\title{
Prozdrowotny styl życia młodzieży w wieku 11-15 lat inwestycją w przyszłość społeczeństwa
}

\section{A healthy lifestyle of young people aged 11-15 as an investment in the future of the society}

\section{Streszczenie:}

Przez prozdrowotny styl życia rozumie się świadome działanie ukierunkowane na zwiększenie potencjału własnego zdrowia i eliminację zachowań zagrażających zdrowiu. Na kształtowanie takiego światopoglądu młodzieży ma wpływ rodzina, szkoła, grupa rówieśnicza, media. Środowiska te powinny tworzyć u młodego człowieka poczucie obowiązku dbania o własny potencjał zdrowotny i dokonywanie świadomego wyboru prozdrowotnego stylu życia. Celem artykułu jest zwrócenie uwagi na rolę zachowań prozdrowotnych młodzieży w wieku 11-15 lat, jako ważnego czynnika w tworzeniu zdrowego społeczeństwa. Analizie poddano dane Instytutu Matki i Dziecka zawarte w raporcie „Zdrowie uczniów w 2018 roku na tle nowego modelu badań HBSC (Health Behaviour in School-aged Children)" oraz dane $\mathrm{z}$ analogicznego raportu z 2014 roku „Zdrowie i zachowania zdrowotne młodzieży szkolnej w Polsce na tle wybranych uwarunkowań socjodemograficznych". Z przeprowadzonej analizy wybranych danych Instytutu Matki i Dziecka wynika, iż młodzież jest w większości świadoma znaczenia zachowań prozdrowotnych dla swojego zdrowia w przyszłości.

Słowa kluczowe: styl życia, młodzież, promocja zdrowia

Abstract:

A healthy lifestyle is understood as a conscious action aimed at increasing the potential of one's health and eliminating behaviours threatening it. The family, school, peer 
M. Sander-Grabowska, B. Przystaś - Prozdrowotny styl życia...

groups and media influence the shaping of such a worldview among children and youth. These environments should create a young person's sense of obligation to care for their own health potential and to make informed choices concerning a healthy lifestyle. The aim of the article is to draw attention to the role of health-promoting behaviours of adolescents aged 11-15 as an important factor in creating a healthy society. The data of the Institute of Mother and Child included in the report „Health of students in 2018 in the light of the new HBSC (Health Behaviour in School-aged Children) research model” and the data from an analogical report from 2014 „Health and health behaviours of school youth in Poland in the context of selected sociodemographic conditions". The analysis of selected data presented by the Institute of Mother and Child shows that young people are mostly aware of the importance of health-promoting behaviours for their health in the future.

Keywords: lifestyle, youth, health promotion

\section{Wprowadzenie}

$\mathrm{Na}$ kształtowanie nawyków prozdrowotnych ma wpływ wiele czynników. Należą do nich m.in. środowisko rodzinne, szkoła, rówieśnicy oraz środki masowego przekazu. Rodzina odgrywa zasadniczą rolę $\mathrm{w}$ rozwoju młodej osoby. $\mathrm{W}$ rodzinnym środowisku, które pełni wychowawczą rolę, młody człowiek zaczyna przejmować wyznawane wartości, zachowania oraz sposoby reagowania na dane sytuacje ${ }^{1}$. Rodzice dostarczają modeli zachowań zdrowotnych związanych z aktywnością fizyczną, zdrową dietą, higieną². Uniemożliwiają bądź niestety niekiedy zapewniają dostęp do substancji psychoaktywnych, takich jak np. alkohol. Nieprawidłowości w zakresie zachowań zdrowotnych prezentowanych przez dzieci i młodzież mogą powodować negatywne następstwa zdrowotne sięgające wieku dorosłego ${ }^{3}$.

Teoria społecznego uczenia się mówi, iż wzorce spostrzegane w najbliższym otoczeniu i dodatkowo wzmacniane podlegają utrwale-

\footnotetext{
${ }^{1}$ H. Liberska, A. Malina, D. Suwalska-Barancewicz, Funkcjonowanie współczesnych młodych ludzi w zmieniającym się świecie, Warszawa 2012, s. 216.

2 K. Borzucka-Sitkiewicz, Promocja zdrowia i edukacja zdrowotna, Kraków 2006, s.10.

${ }^{3}$ M. Zadworna-Cieślak, N. Ogińska-Bulik, Zachowania zdrowotne młodzieży uwarunkowania podmiotowe i rodzinne, Warszawa 2011, s. 66.
} 
niu. Bliskie otoczenie młodego człowieka może zatem wywierać istotny wpływ na jego wybory w zakresie zdrowia. Zarówno koledzy, przyjaciele, jak i nauczyciele ze szkoły mogą stanowić dla nastolatka swoisty model zachowań zdrowotnych. Im bardziej nastolatek identyfikuje się ze środowiskiem rówieśniczym, tym więcej zachowań prozdrowotnych od niego przejmie. Problem może pojawić się w sytuacji, kiedy grupa rówieśnicza wykazuje zachowania szkodliwe dla zdrowia ${ }^{4}$.

Szkoła (obok rodziny) pełni istotną rolę w edukacji zdrowotnej młodzieży. Korzystne środowisko psychospołeczne w środowisku szkolnym stanowi dla nastolatków źródło istotnego wsparcia. Czynnikiem ochronnym przed sięganiem po środki psychoaktywne, takie jak alkohol, narkotyki, papierosy, jest pomoc ze strony nauczycieli. Z kolei przyjazne środowisko rówieśnicze stanowi czynnik zmniejszający ryzyko wystąpienia u nastolatków zaburzeń psychicznych, a także doświadczania przemocy ze strony kolegów ${ }^{5}$.

Zgodnie z teorią społeczno-poznawczą młodzi ludzie uczą się zachowań, obserwując innych, zarówno w realnym życiu, jak i w mediach ${ }^{6}$. Dzięki temu kształtują wartości oraz nabywają umiejętności. Niepokojącym jest fakt, iż chętnie oglądane przez młodzież teledyski, materiały $\mathrm{w}$ mediach społecznościowych kładą głównie nacisk na promowanie seksualności oraz erotyzmu. Prezentują np. wypaczony obraz kobiecej seksualności, przedstawiając kobiety jako obiekty seksualne ${ }^{7}$. Również Internet ma tendencję do zniekształcania rzeczywistości. Młodzież przyznaje, że dzięki niemu ma dostęp do wszelkich informacji i form rozrywki. Niestety, jednak dużo łatwiej jest tutaj znaleźć informacje zawierające negatywne treści, niż strony promujące prozdrowotny styl życia ${ }^{8}$. Według Barbary Woynarowskiej zachowania prozdrowotne to (...) działania intencjonalne (celowe), świado-

\footnotetext{
${ }^{4}$ Ibidem, s. 76.

5 Ibidem, s.78.

${ }^{6}$ H. Liberska, A. Malina, D. Suwalska-Barancewicz, Funkcjonowanie..., op. cit., s. 237.

7 Ibidem, s. 239.

8 Ibidem, s. 241.
} 
M. Sander-Grabowska, B. Przystaś - Prozdrowotny styl życia...

mie podjęte przez człowieka w celu ochrony, umacniania, zwiększania potencjału swojego zdrowia 9 .

\section{Zachowania sprzyjające zdrowiu}

Prozdrowotny styl życia obejmuje zachowania:

1. Związane ze zdrowiem fizycznym i psychospołecznym:

- dbałość o ciało i najbliższe otoczenie,

- aktywność fizyczna,

- racjonalne żywienie,

- odpowiednia ilość snu,

- dawanie i przyjmowanie wsparcia społecznego,

- umiejętne radzenie sobie z problemami i nadmiernym stresem;

2. Prewencyjne:

- samokontrola zdrowia,

- badania profilaktyczne,

- bezpieczne zachowania seksualne;

3. Niepodejmowanie zachowań ryzykownych:

- niepalenie tytoniu, unikanie biernego palenia,

- niespożywanie alkoholu,

- nieużywanie innych substancji psychoaktywnych,

- nienadużywanie leków,

- unikanie ryzykownych zachowań behawioralnych (uzależnienie od Internetu, zakupów) ${ }^{10}$.

Dieta może być zarówno czynnikiem służącym zdrowiu, jak i przyczyną chorób. Dobrze zbilansowana stanowi warunek prawidłowego rozwoju młodzieży. Nieprawidłowa może prowadzić do takich cho-

\footnotetext{
9 B. Woynarowska, Edukacja zdrowotna, Warszawa 2017, s. 59.

10 Ibidem, s. 58-60.
} 
rób, jak np. choroba wieńcowa, nadciśnienie tętnicze, otyłość, cukrzyca, próchnica ${ }^{11}$.

Palenie tytoniu jest dominującą przyczyną chorób układu krążenia oraz nowotworów. Bierne palenie, na które często narażone są dzieci i młodzież, może prowadzić do chorób układu oddechowego, chorób ucha środkowego, rozwoju astmy. Jest ono zatem bardziej niebezpieczne, niż palenie czynne ${ }^{12}$. Dzieci palących rodziców cechują się gorszym rozwojem psychofizycznym. Palenie tytoniu przez młodzież może mieć konsekwencje zdrowotne w przyszłości. Wiadomo bowiem, iż prowadzi do rozwoju nowotworów, przewlekłych chorób układu oddechowego oraz udarów mózgu ${ }^{13}$.

Nadużywanie alkoholu ma wpływ zarówno na zdrowie, jak i społeczne funkcjonowanie człowieka. Korzystanie z alkoholu przed 18 rokiem życia jest zachowaniem ryzykownym dla zdrowia młodzieży. Może być powodem marskości wątroby, nowotworów przełyku, krtani, wątroby, żołądka oraz chorób układu krążenia ${ }^{14}$. Jest także przyczyną powstawania urazów i wypadków. Nadużywanie alkoholu może prowadzić do utraty pracy, do rozpadu więzi rodzinnych oraz do odebrania praw rodzicielskich. Jest więc istotnym problemem społecznym ${ }^{15}$.

Zalecany dzienny czas umiarkowanej aktywności fizycznej dla młodzieży to około godzina dziennie. Wykazuje ona liczne korzyści dla organizmu. Obniża ciśnienie tętnicze krwi, poprawia wydolność serca i płuc, obniża poziom cholesterolu, pozwala utrzymać prawidłową masę ciała, zmniejsza ryzyko wystąpienia chorób sercowonaczyniowych, osteoporozy, nadciśnienia, cukrzycy typu 2. Ruch pełni istotną rolę w prawidłowym rozwoju psychofizycznym dzieci i mło-

\footnotetext{
${ }_{11}$ M. Zadworna-Cieślak, N. Ogińska-Bulik, Zachowania..., op. cit., s. 19.

${ }^{12}$ A. Andruszkiewicz, M. Banaszkiewicz, Promocja zdrowia dla studentów studiów licencjackich kierunku pielęgniarstwo i położnictwo, Warszawa 2010, s. 125.

13 M. Zadworna-Cieślak, N. Ogińska-Bulik, Zachowania..., op. cit., s. 21.

14 B. Kulik, A. Pacian, Zdrowie publiczne, Warszawa 2014, s. 81-83.

15 M. Zadworna-Cieślak, N. Ogińska-Bulik, Zachowania..., op. cit., s. 22.
} 
M. Sander-Grabowska, B. Przystaś - Prozdrowotny styl życia...

dzieży ${ }^{16}$. Należy również pamiętać, że aktywność fizyczna pełni funkcję nie tylko prewencyjną, ale również terapeutyczną ${ }^{17}$.

Innymi zachowaniami mającymi wpływ na zdrowie są te, które posiadają znamiona uzależnienia oraz zachowania prewencyjne. Do pierwszej grupy zaliczyć należy nadużywanie narkotyków, zbyt długi czas spędzany w Internecie. Do drugiej grupy należą m.in.: poddawanie się badaniom profilaktycznym, aktywność fizyczna, radzenie sobie ze stresem, prewencyjne zachowania seksualne, samobadanie piersi, samobadanie jąder, właściwe odżywianie, przestrzeganie zaleceń zdrowotnych, właściwa organizacja czasu wolnego, używanie pasów bezpieczeństwa $\mathrm{w}$ samochodzie itp. ${ }^{18}$ Uzależnienia wiążą się ze zwiększonym ryzykiem powstawania chorób lub przedwczesnej śmierci. Działania prewencyjne mają na celu zapobieganie problemom, zaburzeniom, chorobom, dysfunkcjom zanim one wystąpią ${ }^{19}$.

Analizie poddano dane Instytutu Matki i Dziecka zawarte w raporcie „Zdrowie uczniów w 2018 roku na tle nowego modelu badań HBSC (Health Behaviour in Schoolaged Children)", które przeprowadzono na terenie 16 województw w Polsce ${ }^{20}$. Health Behaviour in Schoolaged Children są badaniami międzynarodowymi realizowanymi co cztery lata od 1982 roku. Dotyczą one zachowań zdrowotnych wśród młodzieży szkolnej. Bierze w nich udział coraz większa liczba krajów. Dla porównania analizie poddano dane Instytutu Matki i Dziecka zawarte w raporcie „Zdrowie i zachowania zdrowotne młodzieży szkolnej w Polsce na tle wybranych uwarunkowań socjodemograficznych" z 2014 r. ${ }^{21}$

16 Ibidem, s.23.

17 M. Świderska, Styl życia i zachowania prozdrowotne- wybrane konteksty, Łódź 2012, s. 121.

18 M. Zadworna-Cieślak, N. Ogińska-Bulik, Zachowania..., op. cit., s. 23-24.

19 B. Woynarowska, Edukacja..., op. cit., s. 114.

20 J. Mazur, A. Małkowska-Szkutnik, Zdrowie uczniów w 2018 roku na tle nowego modelu badań HBSC (Health Behaviour in School-aged Children), Warszawa 2018.

21 J. Mazur, Zdrowie i zachowania zdrowotne młodzieży szkolnej $w$ Polsce na tle wybranych uwarunkowań socjodemograficznych, Warszawa 2014. 
Tabela 1. przedstawia spożycie wybranych produktów w 2014 i 2018 roku wśród młodzieży w wieku 11-15 lat. Porównano spożycie produktów korzystnych i niekorzystnych dla zdrowia.

Tabela 1. Odsetek młodzieży w wieku 11-15 lat, która codziennie spożywała produkty korzystne i niekorzystne dla zdrowia w 2014 i $2018 \mathrm{r}$.

\begin{tabular}{|c|c|c|c|}
\hline \multicolumn{2}{|c|}{ Spożycie wybranych produktów } & $\mathbf{2 0 1 4}$ rok & $\mathbf{2 0 1 8}$ rok \\
\hline $\begin{array}{c}\text { Produkty korzystne } \\
\text { dla zdrowia }\end{array}$ & Warzywa & $29,3 \%$ & $34,2 \%$ \\
\hline $\begin{array}{c}\text { Produkty niekorzystne } \\
\text { dla zdrowia }\end{array}$ & Owoce & $33,8 \%$ & $38,2 \%$ \\
\hline & $\begin{array}{c}\text { Słodycze } \\
\text { napoje }\end{array}$ & $72,5 \%$ & $69,9 \%$ \\
\hline
\end{tabular}

Źródło: J. Mazur, A. Małkowska-Szkutnik, Zdrowie uczniów w 2018 roku na tle nowego modelu badań HBSC (Health Behaviour in School-aged Children), Instytut Matki i Dziecka, Warszawa 2018.

Według danych Instytutu Matki i Dziecka z raportu „Zdrowie uczniów w 2018 roku na tle nowego modelu badań HBSC (Health Behaviour in School-aged Children)", zwiększa się świadomość młodych ludzi dotycząca znaczenia dobrze zbilansowanej dieta dla zdrowia człowieka. W 2018 roku o blisko 5\% wzrosło spożycie warzyw i owoców w stosunku do 2014 roku. Na przestrzeni tych lat o 3\% uległo zmniejszeniuspożycie słodyczy. W 2014 roku 56,8\% młodzieży przyznało, iż pije słodkie napoje. W 2018 roku odsetek ten zmniejszył się do niecałych $45 \%$ badanych ${ }^{22}$.

22 J. Mazur, A.Małkowska-Szkutnik, Zdrowie..., op. cit., s. 108. 
M. Sander-Grabowska, B. Przystaś - Prozdrowotny styl życia...

Tabela 2. przedstawia częstotliwość palenia tytoniu wśród młodzieży w grupie wiekowej 11-15 lat. Młodzież odpowiadała na pytanie, ile razy w tygodniu zdarza się jej palić tytoń.

Tabela 2. Częstość palenia tytoniu wśród młodzieży w wieku 11-15 lat

\begin{tabular}{|c|c|c|c|}
\hline Nie palę & $\begin{array}{c}\text { Palę rzadziej niż } \\
1 \text { raz w } \\
\text { tygodniu }\end{array}$ & $\begin{array}{c}\text { Co najmniej } \\
1 \text { raz } \\
\text { w tygodniu, ale } \\
\text { nie codziennie }\end{array}$ & Palę codziennie \\
\hline $87,8 \%$ & $5,5 \%$ & $3,3 \%$ & $3,3 \%$ \\
\hline
\end{tabular}

Źródło: J. Mazur, A. Małkowska-Szkutnik, Zdrowie uczniów..., op. cit.

Bardzo optymistycznie wygląda statystyka dotycząca palenia tytoniu w badanej grupie wiekowej nastolatków11-15 lat. Zdecydowana większość bo aż 87,8\% z nich podało, iż nie pali tytoniu wcale. Tylko 3,3\% młodzieży przyznało, iż robi to codziennie. Co 10-ta badana osoba potwierdziła, iż pali okazjonalnie ${ }^{23}$. Spożycie alkoholu wśród młodzieży 11-15 lat przedstawia Tabela 3. Badani odpowiadali na pytanie, ile razy w życiu zdarzyło im się spożywać alkohol.

Tabela 3. Częstość picia alkoholu w życiu wśród młodzieży w wieku 11-15 lat.

\begin{tabular}{|c|c|c|c|c|}
\hline $\begin{array}{c}\text { Nie piję } \\
\text { alkoholu }\end{array}$ & $\begin{array}{c}\text { Piłem/am } \\
1-5 \mathrm{dni} \\
\text { w życiu }\end{array}$ & $\begin{array}{c}\text { Piłem/am } \\
\text { 6-9 dni } \\
\text { w życiu }\end{array}$ & $\begin{array}{c}\text { Piłem/am } \\
10-19 \mathrm{dni} \\
\text { w życiu }\end{array}$ & $\begin{array}{c}\text { Piłem/am } \\
20 \mathrm{dni} \\
\text { i więcej }\end{array}$ \\
\hline $65,4 \%$ & $19,3 \%$ & $4 \%$ & $3,8 \%$ & $7,4 \%$ \\
\hline
\end{tabular}

Źródło: J. Mazur, A. Małkowska-Szkutnik, Zdrowie uczniów..., op. cit.

23 Ibidem, s. 133. 
Ponad 65,4\% młodzieży w wieku 11-15 lat podało, że nigdy nie piło alkoholu. Prawie 20\% badanych przyznało się do spożywania alkoholu do 5 razy w swoim życiu. Tylko $4 \%$ osób potwierdziło, iż zrobiło to do 9 razy w życiu. Ponad $11 \%$ młodych ludzi piło alkohol od 10-ciu do 20-stu razy w ciągu swojego życia ${ }^{24}$.

Podejmowanie aktywności fizycznej wśród młodzieży w wieku 1115 lat przedstawia Tabela 4. Młodzież odpowiadała na pytanie, ile razy w tygodniu podejmuje aktywność fizyczną.

Tabela 4. Częstość podejmowania umiarkowanej aktywności fizycznej wśród młodzieży w wieku 11-15 lat

\begin{tabular}{c|c|c|c|}
\hline Jestem & Jestem & Jestem & Jestem \\
aktywny/a & aktywny/a & aktywny/a & aktywny/a \\
fizycznie & fizycznie & fizycznie & fizycznie \\
0-1 dni & $2-4$ dni & $5-6$ dni & 7 dni \\
w tygodniu & w tygodniu & w tygodniu & w tygodniu \\
\hline $9,9 \%$ & $44,4 \%$ & $28,5 \%$ & $17,2 \%$ \\
\hline
\end{tabular}

Źródło: J. Mazur, A. Małkowska-Szkutnik, Zdrowie uczniów..., op. cit.

Co 10-ty nastolatek w wieku 11-15 lat prawie wcale nie podejmuje aktywności fizycznej. Ponad $44,4 \%$ dzieci robi to $2-4$ razy w tygodniu. Codziennie lub prawie codziennie aktywnych fizycznie jest $45,7 \%$ młodzieży w badanej grupie 25 .

Tabela 5. dotyczy korzystania z marihuany przez osoby w wieku 15 lat. Badani określali, ile razy w swoim życiu zdarzyło im się sięgać po marihuanę.

\footnotetext{
24 Ibidem, s. 136.

25 Ibidem, s. 90.
} 
M. Sander-Grabowska, B. Przystaś - Prozdrowotny styl życia...

Tabela 5. Częstość korzystania z marihuany przez młodzież w wieku 15 lat

\begin{tabular}{c|c|c|c|c|}
$\begin{array}{c}\text { Nigdy nie } \\
\text { korzystałem } \\
\text { /am }\end{array}$ & $\begin{array}{c}\text { Korzystałem } \\
\text { /am 1-5 dni } \\
\text { w życiu }\end{array}$ & $\begin{array}{c}\text { Korzystałem } \\
\text { /am 6-9 dni } \\
\text { w życiu }\end{array}$ & $\begin{array}{c}\text { Korzystałem } \\
\text { /am 10-19 } \\
\text { dni } \\
\text { w życiu }\end{array}$ & $\begin{array}{c}\text { Korzystałem } \\
\text { /am 20 dni } \\
\text { i więcej }\end{array}$ \\
\hline $85,5 \%$ & $9,4 \%$ & $1,3 \%$ & $1,1 \%$ & $2,7 \%$ \\
\hline
\end{tabular}

Źródło: J. Mazur, A. Małkowska-Szkutnik, Zdrowie uczniów..., op. cit.

Nigdy w życiu nie paliło marihuany 85,5\% badanych osób. Ponad 9\% młodzieży przyznało się, że robiło to do 5-ciu razy w życiu. Jeden nastolatek na 100 badanych przyznał, iż palił 10-20 razy. Prawie 3\% badanych potwierdziło, iż zrobiło to więcej, niż 20 razy w życiu. ${ }^{26}$

W 2014 r. Instytut Matki i Dziecka opracował raport „Zdrowie i zachowania zdrowotne młodzieży szkolnej w Polscena tle wybranych uwarunkowań socjodemograficznych" i przedstawił w nim wyniki badań HBSC (Health Behaviour in Schoolaged Children) z lat 2010$2014^{27}$.

Tabela 6. Przedstawia spożycie produktów korzystnych i niekorzystnych dla zdrowia wśród młodzieży w wieku 11-15 lat w 2010 roku.

Porównując dane z 2010 r. z danymi z 2018 r., można stwierdzić, że o ponad połowę zwiększyło się spożycie słodyczy wśród młodzieży w wieku 11-15 lat. W 2018 r. w porównaniu do 2010 r. prawie o 18\% zwiększył się odsetek młodych osób, które codziennie piją słodkie napoje. Na przestrzeni tych lat zwiększyło się codzienne spożycie warzyw wśród badanej grupy wiekowej (blisko 11\%), natomiast spożycie owoców wzrosło jedynie o 4\%28.

26 Ibidem, s.140.

27 J. Mazur, Zdrowie i zachowania zdrowotne młodzieży szkolnej w Polsce na tle wybranych uwarunkowań socjodemograficznych, Warszawa 2014.

28 Ibidem, s. 150-151. 
Tabela 6. Odsetek młodzieży w wieku 11-15 lat, która codziennie spożywała produkty korzystne i niekorzystne dla zdrowia w $2010 \mathrm{r}$.

\begin{tabular}{|r||c|c|}
\hline \multicolumn{2}{|c|}{ Spożycie wybranych produktów } & 2010 rok \\
\hline $\begin{array}{c}\text { Produkty korzystne dla } \\
\text { zdrowia }\end{array}$ & Warzywa & $30,7 \%$ \\
\hline $\begin{array}{c}\text { Produkty niekorzystne dla } \\
\text { zdrowia }\end{array}$ & Owoce & $27,3 \%$ \\
\hline
\end{tabular}

Źródło: J. Mazur, Zdrowie i zachowania zdrowotne młodzieży szkolnej w Polsce na tle wybranych uwarunkowań socjodemograficznych, Warszawa 2014.

Tabela 7. przedstawia odsetek młodzieży w wieku 11-15 lat, która deklarowała bądź nie deklarowała palenia tytoniu oraz wskazywała częstotliwość sięgania po papierosy.

Tabela 7. Częstość palenia tytoniu wśród młodzieży w wieku 11-15 lat w $2010 \mathrm{r}$.

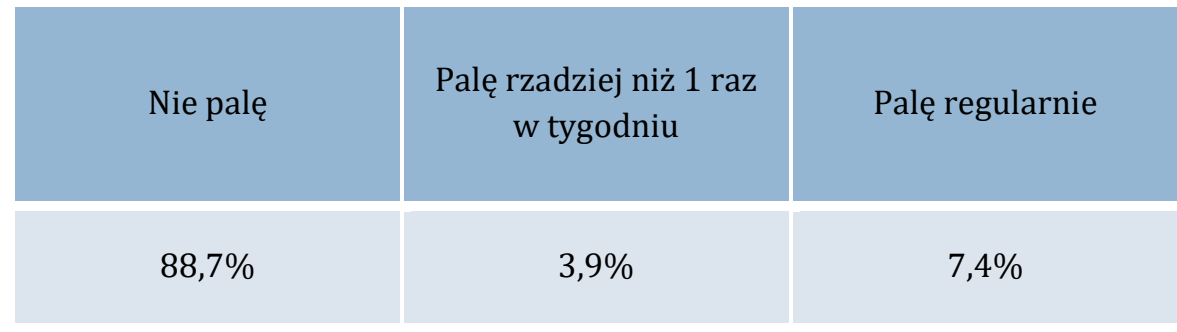

Źródło: J. Mazur, Zdrowie i zachowania zdrowotne..., op. cit.

Porównując dane z 2010 i 2018r., nie stwierdza się widocznych różnic w ilości młodzieży niepalącej. Nieznacznie wzrosła liczba osób palących okazjonalnie - w 2010 r. - 3,9\%, w 2018 r. - 5,5\%. Mniej 
M. Sander-Grabowska, B. Przystaś - Prozdrowotny styl życia...

badanych osób pali regularnie. W 2010 r. deklarowało palenie regularne 7,4\% badanych, a w 2018 r. - 6,6\% respondentów ${ }^{29}$.

W Tabeli 8. przedstawiono odsetek młodzieży pijącej oraz niepijącej alkohol oraz częstotliwość spożywania napojów alkoholowych.

Tabela 8. Częstość picia alkoholu w życiu wśród młodzieży w wieku 11-15 lat w $2010 \mathrm{r}$.

\begin{tabular}{|c|c|c|c|c|}
\hline $\begin{array}{c}\text { Nie piję } \\
\text { alkoholu }\end{array}$ & Piję rzadko & $\begin{array}{c}\text { Piję raz } \\
\text { w miesiącu }\end{array}$ & $\begin{array}{c}\text { Piję raz } \\
\text { w tygodniu }\end{array}$ & $\begin{array}{c}\text { Piję } \\
\text { codziennie }\end{array}$ \\
\hline $57,4 \%$ & $29,2 \%$ & $7 \%$ & $4,9 \%$ & $2,5 \%$ \\
\hline
\end{tabular}

Źródło: J. Mazur, Zdrowie i zachowania zdrowotne..., op. cit.

W 2010 r. 57,4\% młodzieży w wieku 11-15 lat deklarowało, iż w ogóle nie pije alkoholu. Odsetek ten zwiększył się w 2018 r. - niekorzystanie z alkoholu deklarowało już $65,4 \%$ badanych $^{30}$.

Tabela 9. przedstawia częstotliwość podejmowania aktywności fizycznej w 2010 r. przez osoby w wieku 11-15 lat oraz odsetek młodych ludzi podejmujących taką aktywność.

Tabela 9. Częstość podejmowania umiarkowanej aktywności fizycznej wśród młodzieży w wieku 11-15 lat w 2010 r.

\begin{tabular}{c|c|c|c|}
\hline Jestem & Jestem & Jestem & Jestem \\
aktywny/a & aktywny/a & aktywny/a & aktywny/a \\
fizycznie & fizycznie & fizycznie & fizycznie \\
$0-1$ dni & $2-4$ dni & $5-6$ dni & 7 dni \\
w tygodniu & w tygodniu & w tygodniu & w tygodniu \\
\hline $1,7 \%$ & $47,9 \%$ & $27,1 \%$ & $20,2 \%$ \\
\hline
\end{tabular}

Źródło: J. Mazur, Zdrowie i zachowania zdrowotne..., op. cit.

29 Ibidem, s. 172.
30 Ibidem, s. 179. 
Zauważa się, iż w 2018 r. w porównaniu z 2010 r. wzrósł odsetek młodzieży w wieku 11-15 lat, która w ogóle nie podejmuje aktywności fizycznej - w 2010 r. 1,7\% badanych, w 2018 r. - prawie 10\% respondentów. Na przestrzeni tych lat zmniejszeniu uległ także nieznacznie odsetek młodych osób podejmujących umiarkowaną aktywność fizyczną. W 2010 r. prawie 48\% osób deklarowało, że ćwiczy 2-4 dni w tygodniu, w 2018 r. - ponad 44\% badanych. Codzienną aktywność w 2010 r. zadeklarowało ponad 20\% respondentów, a w 2018 r. ponad $17 \%$ osób ${ }^{31}$.

Odsetek młodzieży oraz częstotliwość korzystania z marihuany przedstawia Tabela 10. Dane w niej zawarte pochodzą z $2010 \mathrm{r}$.

Tabela 10. Częstość korzystania z marihuany przez młodzież w wieku 15 lat w $2010 \mathrm{r}$.

\begin{tabular}{|c|c|c|c|c|}
$\begin{array}{c}\text { Nigdy nie } \\
\text { korzystałem }\end{array}$ & $\begin{array}{c}\text { Korzystałem } \\
\text { /am }\end{array}$ & $\begin{array}{c}\text { Korzystałem } \\
\text { /am }\end{array}$ & $\begin{array}{c}\text { Korzystałem } \\
\text { /am }\end{array}$ & $\begin{array}{c}\text { Korzystałem } \\
\text { /am }\end{array}$ \\
$\begin{array}{c}\text { z marihuany } \\
\text { w życiu }\end{array}$ & $\begin{array}{c}6-9 \mathrm{dni} \\
\text { w życiu }\end{array}$ & $\begin{array}{c}10-19 \mathrm{dni} \\
\text { w życiu }\end{array}$ & $\begin{array}{c}20 \mathrm{dni} \\
\text { i więcej }\end{array}$ \\
\hline $76,2 \%$ & $13,5 \%$ & $2,3 \%$ & $1,8 \%$ & $6,7 \%$ \\
\hline
\end{tabular}

Źródło: J. Mazur, Zdrowie i zachowania zdrowotne..., op. cit.

Porównując dane z 2010 i 2018 r., należy zauważyć, iż zwiększyła się świadomość młodzieży w wieku 15 lat dotycząca szkodliwości korzystania z marihuany. 0 prawie $10 \%$ zwiększyła się liczba osób, które nigdy nie paliły marihuany - w 2010 r. - ponad 76\%, w 2018 r. ponad $85 \%$. Zmniejszeniu uległ także odsetek młodzieży palącej marihuanę często. W 2010 r. dotyczyła ta sytuacja 6,7\% badanych, w 2018 r. tylko $2,7 \%$ osób $^{32}$.

\footnotetext{
31 Ibidem, s. 123.

32 Ibidem, s. 189.
} 
M. Sander-Grabowska, B. Przystaś - Prozdrowotny styl życia...

\section{Podsumowanie}

Z przeprowadzonej analizy wybranych danych Instytutu Matki i Dziecka wynika, iż młodzież jest świadoma znaczenia zachowań prozdrowotnych dla utrzymania zdrowia w przyszłości. Wpływ na zachowania prozdrowotne młodzieży ma zarówno rodzina, rówieśnicy, jak i środowisko szkolne. Istotną rolę w utrzymaniu zdrowia odgrywa jego promocja w społeczeństwie ${ }^{33}$.

Ministerstwo Zdrowia opracowało Narodowy Program Zdrowia na lata 2016-2020, którego wybrane cele są skierowane specjalnie do młodzieży ${ }^{34}$. Jako przykłady można podać:

- Kształtowanie świadomości zdrowotnej i motywacji do dbania o zdrowie u dzieci i młodzieży szkolnej ze szczególnym uwzględnieniem problematyki używania substancji psychoaktywnych i ich negatywnych następstw.

- Prowadzenie działań edukacyjnych, w tym kampanii społecznych, adresowanych do różnych grup docelowych, w szczególności do dzieci, młodzieży i rodziców na temat zagrożeń wynikających z używania środków odurzających, substancji psychotropowych i innych leków, co może prowadzić do uzależnienia.

- Upowszechnienie wiedzy o zagrożeniach wynikających z kontaktu dzieci i młodzieży z materiałami zawierającymi treści pornograficzne, uprzedmiatawiające i seksualizujące.

- Upowszechnianie programów profilaktycznych opartych na podstawach naukowych, które zapobiegają zagrożeniom związanym z dostępem dzieci i młodzieży do treści pornograficznych, uprzedmiatawiających i seksualizujących.

- Prowadzenie zintegrowanej, skojarzonej profilaktyki próchnicy zębów, w tym organizacja bezpłatnej opieki stomatologicznej (profilaktycznej i leczenia) dla dzieci i młodzieży. S. 0 .

33 K. Borzucka-Sitkiewicz, Promocja zdrowia i edukacja zdrowotna, Kraków 2006,

34 „Narodowy Program Zdrowia na lata 2016-2020”, https://www.gov.pl/web/ zdrowie/narodowy-program-zdrowia-ogloszenia [dostęp: 29-05-2019]. 
- Ograniczanie presji marketingowej produktów niezalecanych do nadmiernego spożycia, kierowanej w szczególności do dzieci i młodzieży.

- Prowadzenie aktywnej polityki wobec dzieci i młodzieży poprzez działania i programy, działania mające na celu wszechstronny rozwój i rozwijanie konstruktywnych relacji międzyludzkich, wzmacnianie potencjału zdrowia psychicznego dzieci i młodzieży przez wsparcie pozytywnego i harmonijnego rozwoju, kształtowanie osobowości, umiejętności osobistych i społecznych, udzielanie wsparcia $\mathrm{w}$ rozwiązywaniu problemów i kryzysów rozwojowych, podnoszenie odporności psychicznej i poprawę funkcjonowania emocjonalnego ${ }^{35}$.

Przykładami programów profilaktycznych dotyczących edukacji zdrowotnej podejmowanych na rzecz społeczności szkolnej są „NOE”36 oraz „Trzeci elementarz, czyli program siedmiu kroków” (skierowany do młodzieży, nauczycieli i rodziców) ${ }^{37}$. Pierwszy z nich dotyczy problematyki uzależnienia, współuzależnienia i życia w rodzinie alkoholowej. „Trzeci elementarz” związany jest z profilaktyką uzależnień oraz kształtuje umiejętności życiowe i zdrowy styl życia38.

Prozdrowotny styl życia należy promować wśród młodzieży, ponieważ zdrowe społeczeństwo determinuje rozwój ekonomiczny, społeczny oraz osobisty ludzi. Tezy te zawarte są w Karcie Ottawskiej z 1986 roku. Jedynie zdrowe społeczeństwo posiada zdolności do wytwarzana dóbr materialnych, kulturalnych, a poprzez rozwój może osiągnąć dobrobyt 39 .

35 https://www.gov.pl/web/zdrowie/narodowy-program-zdrowia-ogloszenia [dostęp: 29-05-2019].

${ }^{36}$ K. Wojcieszek, NOE cz. I i II, Program profilaktyczny dla młodzieży

$37 \mathrm{https}$ //www.ore.edu.pl/images/files/pdf/Bank_programow_profilaktycznych /klasy/trzeci\%20elementarz.pdf [dostęp: 27-06-2019].

38 https://www.ore.edu.pl/images/files/pdf/Bank_programow_profilaktycznych /klasy/trzeci\%20elementarz.pdf [dostęp: 27-06-2019].

39 Ottawa Charter for Health Promotion; Health Promotion, https://www.who.int /healthpromotion/conferences/previous/ottawa/en/ [dostęp: 27-06-2019]. 
M. Sander-Grabowska, B. Przystaś - Prozdrowotny styl życia...

Choroby w społeczeństwie, przedwczesna umieralność oraz niepełnosprawność mają wymierne skutki społeczne i ekonomiczne dla danego kraju ${ }^{40}$. Zdaniem ekonomistów zdrowie stanowi kapitał, z którego można czerpać określone korzyści ekonomiczne. Lepsze zdrowie oznacza lepszą produktywność, wyższe zarobki oraz pozwala na zaspokojenie potrzeb innych ludzi. Korzystanie ze swojego potencjału zdrowotnego umożliwia człowiekowi spełnione, twórcze, satysfakcjonujące życie zarówno pod względem społecznym, jak i ekonomicznym. Zdrowi ludzie łatwiej wykorzystują swój potencjał; są w stanie zaspokoić swoje potrzeby, osiągać cele oraz mają szansę na dobrą jakość życia ${ }^{41}$.

Rodzice stanowią dla młodzieży inspirację modeli zachowań zdrowotnych. Wzmocnienie określonych zachowań może wpływać na konkretne preferencje młodego człowieka. Promocja zachowań prozdrowotnych i redukcja zachowań przyczyniających się do rozwoju zaburzeń w stanie zdrowia to wyzwanie współczesnej cywilizacji ${ }^{42}$.

\section{Bibliografia:}

Andruszkiewicz A., Banaszkiewicz M., Promocja zdrowia dla studentów studiów licencjackich kierunku pieleggniarstwo i położnictwo, Wyd. PZWL, Warszawa 2010.

Borzucka-Sitkiewicz K., Promocja zdrowia i edukacja zdrowotna, Oficyna Wydawnicza IMPULS, Kraków 2006.

https://www.ore.edu.pl/images/files/pdf/Bank_programow_profilaktyczny ch/klasy/trzeci\%20elementarz.pdf.

Kulik B., Pacian A., Zdrowie publiczne, Wyd. PZWL, Warszawa 2014.

Liberska H., Malina A., Suwalska-Barancewicz D., Funkcjonowanie wspótczesnych młodych ludzi w zmieniającym się świecie, Wyd. Difin, Warszawa 2012.

\footnotetext{
40 B. Woynarowska, Edukacja..., op. cit., s. 28.

41 Ibidem, s. 29.

42 M. Zadworna-Cieślak, N. Ogińska-Bulik, Zachowania..., op. cit., s. 24-47.
} 
Mazur J., Zdrowie i zachowania zdrowotne młodzieży szkolnej w Polsce na tle wybranych uwarunkowań socjodemograficznych, Wyd. Instytut Matki i Dziecka, Warszawa 2014.

Mazur J., Małkowska-Szkutnik A., Zdrowie uczniów w 2018 roku na tle nowego modelu badań HBSC (Health Behaviour in School-aged Children), Wyd. Instytut Matki i Dziecka, Warszawa 2018.

„Narodowy Program Zdrowia na lata 2016-2020”, https://www.gov.pl/web/ zdrowie/narodowy-program-zdrowia-ogloszenia.

Ottawa Charter for Health Promotion; Health Promotion, 1986, https:// www.who.int/healthpromotion/conferences/previous/ottawa/en/m.

Świderska M., Styl życia i zachowania prozdrowotne- wybrane konteksty, Akademii Humanistyczno-Ekonomicznej, Łódź 2012.

Wojcieszek K., NOE cz. I i II, Program profilaktyczny dla młodzieży.

Woynarowska B., Edukacja zdrowotna, Wyd. PWN, Warszawa 2017.

Zadworna-Cieślak M., Ogińska-Bulik N., Zachowania zdrowotne młodzieży uwarunkowania podmiotowe i rodzinne, Wyd. Difin, Warszawa 2011. 